\title{
Vertical distribution and infectious potential of Xiphinema index (Thorne et Allen, 1950) (Nematoda: Longidoridae) in fields affected by grapevine fanleaf virus in vineyards in the Champagne region of France
}

\author{
D Esmenjaud 1, B Walter 2, G Valentin 3, ZT Guo 4, D Cluzeau 5
}

with the technical assistance of $\mathrm{JC}$ Minot ${ }^{1}, \mathrm{R}$ Voisin ${ }^{1}, \mathrm{P}$ Cornuet 2

\author{
1 INRA, Laboratoire de Biologie des Invertébrés, BP 2078, 06606 Antibes Cedex; \\ 2 INRA, Station de Recherches Vigne et Vin, Laboratoire de Pathologie Végétale, BP 507, 68021 Colmar Cedex; \\ ${ }^{3}$ Comité Interprofessionnel du Vin de Champagne, BP 135, 51204 Epernay Cedex, France; \\ 4 Institute of Geology, Chinese Academy of Sciences, PO Box 634, Beijing 100029, China; \\ 5 Université de Rennes, Laboratoire d'Écologie du Sol, URA CNRS 696, 35380 Paimpont, France
}

(Received 19 September 1991; accepted 24 March 1992)

\begin{abstract}
Summary - The distribution of $X$ index in 3 fields infected with grapevine fanleaf virus (GFLV) in the Champagne vine-growing region of France was studied on the basis of samples from each horizon of the pedological profile. The lowest nematode count was observed between 0 and $25 \mathrm{~cm}$ in the field with the highest clay content (Mesnil), and between 0 and $40 \mathrm{~cm}$ in the 2 fields with sandier soil textures. The highest nematode count was detected in the 55$70-\mathrm{cm}$ horizon of the Mesnil field and below $90 \mathrm{~cm}$ in the chalk parent rock for the 2 other fields. In Mesnil, with a high nematode density, ie 5 to 120 individuals per $\mathrm{kg}$ fine soil, the GFLV infectious potential of Xiphinema was determined using the ELISA method in nematode samples of increasing size from 2 to 256 individuals. Differences in absorbance between the field population and a virus-free control population reared on fig roots was observed from sample sizes of two. This method might adequately characterize the infectious potential of a given population.
\end{abstract}

pedological profile / soil particle size / ELISA test

Résumé - Distribution verticale et potentiel infectieux de Xiphinema index (Thorne et Allen, 1950) (Nematoda: Longidoridae) dans des parcelles de vigne atteintes par le virus du court-noué en Champagne. La distribution de $\mathrm{X}$ index dans 3 parcelles atteintes de court-noué du vignoble Champenois est étudiée à partir d'échantillons prélevés au niveau de chaque horizon d'un profil pédologique. Les effectifs les plus faibles sont observés entre 0 et $25 \mathrm{~cm}$ dans la parcelle la plus argileuse (Mesnil) et entre 0 et $40 \mathrm{~cm}$ dans les 2 autres parcelles, de texture plus sableuse. Les effectifs les plus élevés sont retrouvés dans l'horizon $55-70 \mathrm{~cm}$ de la parcelle Mesnil et au-delà de $90 \mathrm{~cm}$ dans la roche mère de craie pour les 2 autres. Au Mesnil où les effectifs sont élevés (5-120 individus par kg de terre fine), l'état infectieux des Xiphinema est établi en détectant, par la méthode ELISA, la présence du virus du courtnoué dans les nématodes répartis en groupes d'effectif croissant de 2 à 256 individus. Une différence de densité optique entre la population de la parcelle et une population témoin non virulifère élevée sur figuier est observée dès la modalité "2 individus». Une telle méthode paraît utilisable pour caractériser l'état infectieux d'une population donnée.

profil pédologique / granulométrie / test ELISA

\section{INTRODUCTION}

Grapevine fanleaf virus (GFLV), transmitted by the nematode Xiphinema index (Thorne et Allen), is a serious problem in many vineyards. The maintenance of soil fertility and the soil conservation in regions under this monoculture re- quires an extensive knowledge of the interactions that occur between the soil and its biological components (Cluzeau et al, 1987).

In France, the geographical distribution of $X$ index extends from the Mediterranean area to the Alsace and Champagne regions (Dalmasso and Caubel, 1966; Esmenjaud, unpublished ob- 
servations). For a given field, the horizontal dispersion of nematodes from the initial introduction point depends mainly on the number of grapevine generations grown in the field since the nematode introduction (Dalmasso, 1970).

The vertical distribution of nematodes in the soil is also a factor to be considered in the control of fanleaf disease of the grapevine. This factor depends on both nematode survival under various climatic and edaphic conditions and on soil and pest management practices such as cultivation practices and pesticide treatments.

The vertical distribution of $X$ index has been studied in pedological trenches in vineyards in the Var department of France (Scotto La Massèse et al, 1988) and in Alsace by drill sampling (Vuittenez, 1961). In a Portuguese vineyard, Silva et al (1988) have studied the relationship between GFLV and its vector as a function of depth.

The aim of the present article is to present the vertical distribution of $X$ index in 3 fields infected with GFLV and examine its relationship with edaphic factors in the Champagne vineyard. The virus infectious "potential" of the field with the highest nematode density is described on the basis of direct detection of the virus in the nematode vector by the ELISA method.

\section{MATERIAL AND METHODS}

Sampling was carried out in 3 fields presenting marked symptoms of fanleaf confirmed by ELISA serodiagnosis on grape leaves: one field located in the Mesnil-sur-Oger district (Côte des Blancs) (11-yearold grapevines on $41 \mathrm{~B}$ rootstock) and 2 (Cum 1 and Cum 2) in the Cumières district (19-year-old grapevines on $41 \mathrm{~B}$, and vines aged over 30 years on unidentified stock, respectively). Cum 1 , located on a $10 \%$ slope had been disinfected with $1000 \mathrm{l} / \mathrm{ha}$ dichloropropene-dichloropropane prior to replanting. Samples were taken from each field from June 18 to 24 , 1989, from an $80-\mathrm{cm}$ wide, 1-m long pedological trench between 4 plants, located at the center of a highly infected area. Since the aim was to determine the vertical distribution and infectious potential of the nematodes in the soil, only one trench was dug per field in the part supposed to contain the highest numbers.

The pedological trenches have been systematically described according to the STIPA (Système de Transfert de I'Information Pédologique et Agronomique Pedological and Agronomic Information Transfer System: Bertrand et al, 1984) terms and report therefrom. The distribution of roots in the profiles has been separately described in greater detail than required by the
STIPA. Individual soil samples for nematological and particle size analysis were collected from each horizon. One 5-kg sample per horizon was dug out at an angle from the trench surface, perpendicular to a vine stock.

Each sample was made up of a number of 200- to $500-\mathrm{g}$ clods, containing any rootlets present and was removed with a hand fork. Each sample was subdivided in the laboratory into $31.7-\mathrm{kg}$ parts which were analyzed separately. Each sub-sample was screened through a $2-\mathrm{mm}$ mesh-size screen. The residue was weighed and the screened portion processed through an Oostenbrink elutriator (flow rate: $5 \mathrm{l} / \mathrm{min}$ ), collected, then screened 3 times through $250-\mu \mathrm{m}$ and $40-\mu \mathrm{m}$ screens, respectively. The corresponding residues were placed on moist cellulose paper held by a coarse screen over a basin filled with water $1 \mathrm{~cm}$ deep, just touching the water's surface. Nematodes migrating to the bottom of the basin were collected on a $5-\mu \mathrm{m}$ screen, counted after 24 and $72 \mathrm{~h}$, then totalled. For each horizon, the population numbers from the 3 subsamples were expressed relative to $1 \mathrm{~kg}$ of fine soil $(<2 \mathrm{~mm})$.

Adult $X$ index and 4th-stage larvae extracted from the Mesnil field were then randomly divided into groups of 2 to 256 individuals (series increasing by multiples of 2). Equivalent groups of virus-free adult $X$ index from populations maintained on fig roots in a greenhouse were taken as controls. The immunoglobulins (lgG) used for ELISA were purified from antiGFLV serum according to the rivanol precipitation method (Hardie and Van Regenmortel, 1977). The ELISA plates were coated with $0.05 \mu \mathrm{g} / \mathrm{ml} \mathrm{lgG}$ for $3 \mathrm{~h}$ at $38^{\circ} \mathrm{C}$, then rinsed 3 times. The nematodes were ground in a Potter micro-blender in the presence of

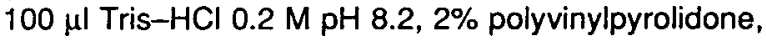
$0.8 \% \mathrm{NaCl}, 0.05 \%$ Tween 20 and carborundum and incubated overnight at $4{ }^{\circ} \mathrm{C}$ in the microtitration plates. After 3 washings, an IgG-biotin conjugate (Guesdon et al, 1979) at 1/20 000 was added and left for $2 \mathrm{~h}$ at $38^{\circ} \mathrm{C}$. Then alkaline phosphatase-labelled streptavidine $(1 / 10000)$ was added and left for $1 \mathrm{~h}$ at $38^{\circ} \mathrm{C}$. The absorbances (A $405 \mathrm{~nm}$ ) were read after 1 and $2 \mathrm{~h}$ incubation of the substrate $(1 \mathrm{mg} / \mathrm{ml} p$ nitrophenylphosphate). The ELISA samples were considered positive when the absorbance values in the nematodes tested were over twice the value of the virus-free nematode controls.

\section{RESULTS}

The vertical distribution of $X$ index together with the pedological profiles and particle size analyses of field horizons are presented in figure 1. The description of the root distribution, based on visual inspection, is given in table 1 . Pure populations of $X$ index were observed in the 3 profiles sampled. $X$ mediterranneum and $X$ vuittenezi, found in certain fields in the Champagne region 

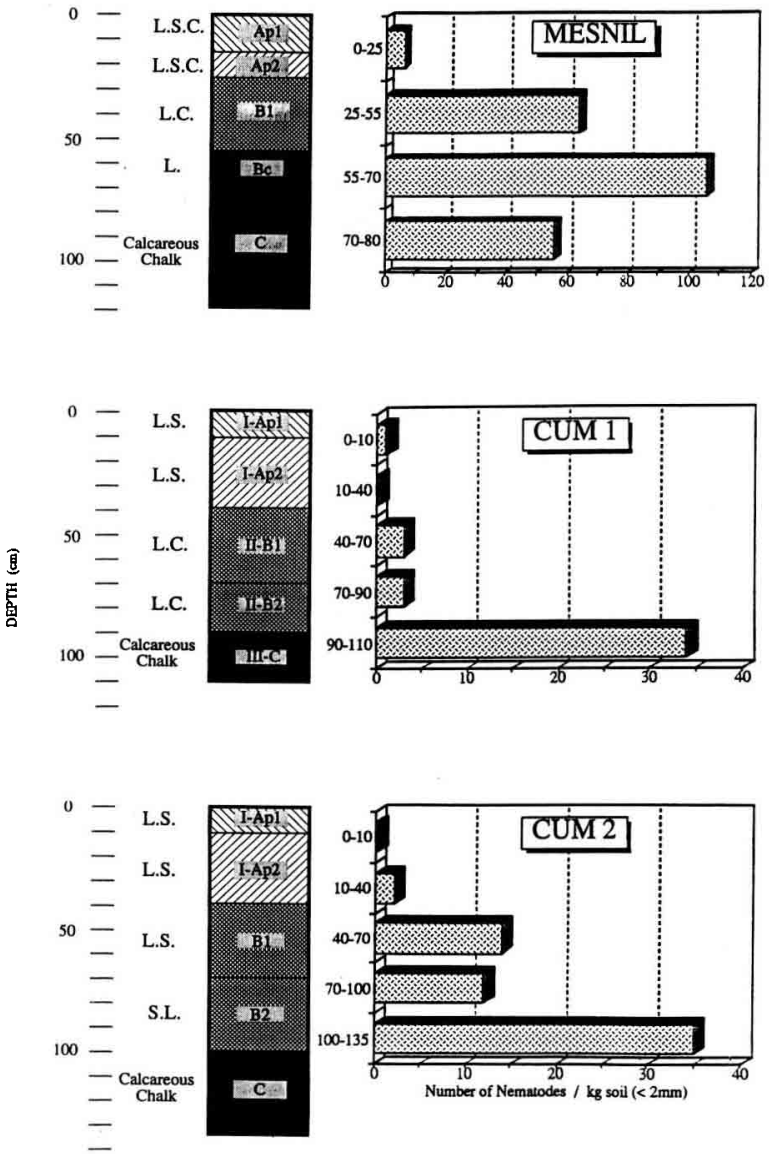

Fig 1. Vertical distribution of $X$ index and profile characteristic for the pedological trenches of the GFLV infected fields in Mesnil sur Oger and Cumières districts of Champagne (average of 3 samplings of $1700 \mathrm{~g}$ of each horizon). LSC: loamy-sandy clay; LC : loamy clay; LS : loamy sand; SL : sandy loam; $L$ : loam.

(Esmenjaud, personal communication), were not detected in this study.

In the Mesnil field, the profile was mainly loamy-clay (Ap1, Ap2 and B1) on degraded chalk $(B C)$. Hence, the soil may be characterized as chalky brown type. The overall profile was rich in casts, with a very marked open porosity system (porosity $>25 \%$ on all measures, with high transmission pore volume). No compact horizons were observed. The good structure of the overall profile had strongly promoted grapevine rooting, which explains the abundance and uniform distribution of different-sized roots. The $X$ index populations showed an increase from the surface to the $55-70 \mathrm{~cm}$ horizon, then a marked decline in numbers with depth. For equivalent horizons, they were substantially more abundant in the Mesnil field than in the other field profiles.

In the Cum1 field, the loamy-sand surface layer (I-Ap1 and I-AP2), built up from exogenous supplies, lay on 2 sandy-clay accumulation horizons above the chalk parent rock. For equivalent horizons - except the surface horizon - roots were less numerous than in the Mesnil field. However, fine roots were still observed in the chalk parent rock below $90 \mathrm{~cm}$. Xiphinema populations were low in the horizons between 0 and $90 \mathrm{~cm}$, reaching 34 individuals per $\mathrm{kg}$ in the chalk. The loamy-sand exogenous soil between 0 and $40 \mathrm{~cm}$ yielded the lowest numbers. The loamy-clay soil in the $40-70 \mathrm{~cm}$ horizon yielded substantially higher numbers.

In the Cum2 field, the texture of the different horizons was lighter: loamy sand between 0 and $70 \mathrm{~cm}$, becoming sandy loam between 70 and $100 \mathrm{~cm}$. Fine roots were observed from the chalk surface to the interior (sampled to 135 $\mathrm{cm}$ ). Nematode populations showed a regular increase from the surface down to the parent rock $(100-135 \mathrm{~cm})$, where they were as numerous as in field Cum1 at the same level of depth.

Figure 2 gives the absorbances (A) obtained by the ELISA method on the basis of increasing nematode samples from the Mesnil field. The curves obtained for field populations and control virus-free nematodes reared in the greenhouse were distinctly separate. Absorbance of field nematodes increased regularly, except for the 16-individual sample, with results above the curve's mean slope. In contrast, control nematodes reached a plateau from the 64-individual sample on.

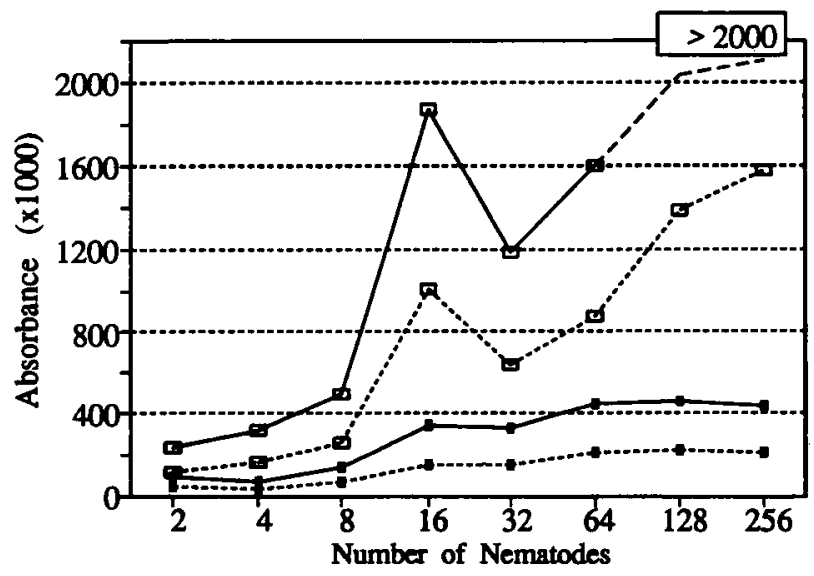

Fig 2. Absorbance evolution (A $405 \mathrm{~nm}$ ) in ELISA of $X$ index obtained from the Mesnil field. Absorbances $(x 1000)$ after 1 and $2 h$ are respectively 14 and 20 in the buffer, 20 and 57 in the healthy vine control, $>2000$ in the diseased vine control. $-\square-$ Mesnil $2 \mathrm{H} ;--$ : control $2 \mathrm{H} ;--\square--$ : Mesnil 1 $\mathrm{H} ;----$ : Mesnil $1 \mathrm{H}$. 
Table I. Vertical distribution of grapevine roots in the profiles studied.

\begin{tabular}{|c|c|c|c|c|c|c|}
\hline & \multirow[t]{2}{*}{ Horizon } & \multirow{2}{*}{$\begin{array}{l}\text { Depth } \\
\text { (cm) }\end{array}$} & \multicolumn{4}{|c|}{ Size of roots ${ }^{1}$} \\
\hline & & & Large & Mediun & $n$ Fine & \\
\hline Mesnil & $\begin{array}{l}\text { Ap1 } \\
\text { Ap2 } \\
\text { B1 } \\
\text { BC } \\
\text { C }\end{array}$ & $\begin{array}{l}0-15 \\
15-25 \\
25-55 \\
55-70 \\
>70\end{array}$ & $\begin{array}{l}0 \\
++++ \\
++ \\
+ \\
0\end{array}$ & $\begin{array}{l}0 \\
++++ \\
++ \\
+ \\
0\end{array}$ & $\begin{array}{l}+++ \\
++++ \\
+++ \\
+ \\
+\end{array}$ & \\
\hline Cum1 & $\begin{array}{l}\text { I-Ap1 } \\
\text { I-Ap2 } \\
\text { II-B1 } \\
\text { II-B2 } \\
\text { II-C }\end{array}$ & $\begin{array}{l}0-10 \\
10-40 \\
40-70 \\
70-90 \\
90-110\end{array}$ & $\begin{array}{l}+ \\
+++ \\
0 \\
0 \\
0\end{array}$ & $\begin{array}{l}+ \\
+++ \\
+ \\
+ \\
0\end{array}$ & $\begin{array}{l}+++ \\
0 \\
+ \\
+ \\
+\end{array}$ & \\
\hline Cum2 & $\begin{array}{l}\text { I-Ap1 } \\
\text { I-Ap2 } \\
\text { II-Ap } \\
\text { II-B1 } \\
\text { II-B2 }\end{array}$ & $\begin{array}{l}0-10 \\
10-40 \\
40-70 \\
70-100 \\
100-135\end{array}$ & $\begin{array}{l}+ \\
++ \\
++ \\
+ \\
0\end{array}$ & $\begin{array}{l}+ \\
++ \\
++ \\
+ \\
0\end{array}$ & $\begin{array}{l}++ \\
+ \\
++ \\
+ \\
+\end{array}$ & \\
\hline 1 Roots & & Large & Medium & Fin & & \\
\hline $\begin{array}{l}\text { Root diamete } \\
\text { Abundance }\end{array}$ & & $\begin{array}{l}>5 \mathrm{~mm} \\
0 \\
<2 \\
2-5 \\
5-10 \\
>10\end{array}$ & $\begin{array}{l}2-5 \mathrm{~mm} \\
0 \\
<5 \\
5-10 \\
10-15 \\
>15\end{array}$ & $\begin{array}{l}<2 \\
0 \\
<15 \\
15-7 \\
75-2 \\
>20\end{array}$ & $\begin{array}{l}m \mathrm{~mm} \\
5 \\
75 \\
200 \\
00\end{array}$ & $\begin{array}{c}0 \\
+ \\
+ \\
+++ \\
++++\end{array}$ \\
\hline
\end{tabular}

(No per $\mathrm{dm}^{2}$ )

\section{DISCUSSION AND CONCLUSIONS}

Substantial nematode populations were detected in the Champagne fields. In the deep horizons their numbers were distinctly higher than the 1-5 individuals per $\mathrm{kg}$ soil most frequently observed in GFLV-infected vineyards (Dalmasso, 1970; Valloton and Perrier, 1990). However, their numbers were still markedly lower than in Mediterranean vineyards (Esmenjaud et al, 1988; Scotto La Massèse et al, 1988). The texture of the soil samples was loamy clay in Mesnil, where the largest populations were observed (56-106 individuals in the 3 deep horizons), whereas it had more sand in the 2 Cumières fields, where lower nematode densities were detected. These findings agree with those by Vuittenez et al (1972), for French vineyards, and by Valloton and Perrier (1990), for Swiss vineyards, observing that heavy soils harbour the highest population densities. Taking variations in vertical distribution into account, the middle and lower horizons show higher densities than do the upper horizons $(0$ to $25-40 \mathrm{~cm}$ ). The lower densities in the upper horizons of the Cum 1 field may be related to soil cultivation (exogenous supply of less contaminated soil and increased nematode mortality) and disinfection prior to planting. Particularly in heavy soils, the efficacy of disinfection is diminished below the cultivation horizon (Esmenjaud et al, 1988). It may be hypothesized that, for the other 2 fields (not disinfected), winter frost, a factor limiting nematode development according to Dalmasso (1970), could have accounted for the lower population densities observed. Nevertheless, the present results demonstrate the inadequacy of soil disinfection in Champagne vineyards and support the findings by Vuittenez (1961) and Valloton and Perrier (1990), who detected $X$ index at $1.40 \mathrm{~m}$ near Colmar (France) and $3.50 \mathrm{~m}$ in the Vinzel region of Switzerland, respectively.

Except for the surface horizon, the only $X$ index-free horizon (10-40 cm in field Cum1) was also that which lacked fine roots. Nevertheless, there was no relationship between nematode density and the quantity (more or less abundant) of fine or thick roots. In a similar study on the cultural profile in fields infested and uninfested by the oat cyst nematode, Heterodera avenae Woll, Rivoal and Riviere (1989) demonstrated that root development was directly modified by the nematode. $X$ index as well as other non endemic virus vectors has much lower densities, particularly in its northern area of distribution and such a direct effect on root development is excluded.

In Mesnil, even the absorbances of the 2-, 4and 8 -individual nematode samples were markedly higher than those of the virus free controls. Hence, the present results, obtained directly from the field, confirm the threshold number of $5-10$ individuals for detecting the virus in nematodes raised on roots of grapevines grown in containers (Bouquet, 1983). Silva et al (1988) also reported positive test responses from a sample size of 5 individuals extracted from fields. However, the absorbance values obtained at $1 \mathrm{~h}$ were lower than those in the present study for both the field and control samples. Catalano et al (1991) have reported detecting the virus in 5 different populations of $X$ index extracted from GFLV infected vineyards, on the basis of groups of 20 female individuals.

The 16-individual subsample showed an absorbance (A) 2.5 times higher for the Mesnil group and around $60 \%$ higher for the control group than that obtained by simple extrapolation from the results for the 8- and 32-individual modalities. This inconsistent value may be due either to a methodological error and/or to the presence of a few highly infected nematodes in this subsample. 
Silva et al (1988) have reported finding many infected nematodes at depths of $90-120 \mathrm{~cm}$ in contaminated vineyards in Portugal. The existence of a deep root system associated with nematodes in the present profiles suggests a similar situation in Champagne.

Plotting the curve on the basis of subsamples (increasing in size by multiples of 2) may be a useful method for assessing the infectious potential of a given population of nematode vectors and the risk of viral infection to grapevines. In practical terms, the application of the method in monitoring the data during the interval between cultivation periods may enable the length of this interval to be limited to that strictly required for eliminating the virus in the nematode vector.

\section{REFERENCES}

Bertrand R, Falipou P, Legros JP (1984) Réseau International de Traitement des Données de Sol (STIPA): Notice pour l'Entrée des Descriptions et Analyses de Sol en Banques de Données. Agence de Coopération Culturelle et Technique, Paris, $140 p$

Bouquet A (1983) Détection immuno-enzymatique du virus du court-noué de la vigne dans son vecteur $X i$ phinema index Thorne et Allen. CR Séances Acad Sci Paris Sér III, 296, 271-273

Catalano L, Savino V, Lamberti F (1991) ELISA for the detection of Grapevine fanleaf nepovirus in Xiphinema index. In: Proc 10th Meet ICVG (Int Council Study Viruses Virus Dis Grapevine) (IC Rumbos, $\mathrm{R}$ Bovey, D Gonsalves, WB Hewitt, GP Martelli, eds) Volos, September 1990

Cluzeau D, Lebouvier M, Trehen P, Bouche MB, Badour C, Perraud A (1987) Relations between earthworms and agricultural practices in the vineyards of Champagne. Preliminary results. In: On Earthworms, Selected Symposis and Monographs UZI (Omodeo P, ed) Modena, Italy, 465-484

Dalmasso A, Caubel G (1966) Répartition des espèces des genres Xiphinema et Longidorus trouvées en France. CR Séances Acad Agric Fr, 440446
Dalmasso A (1970) Influence directe de quelques facteurs écologiques sur l'activité biologique et la distribution des espèces françaises de la famille des Longidoridae (Nematoda: Dorylaimida). Ann Zool Anim 2, 163-200

Esmenjaud D, Pistre R, Bongiovanni M (1988) Activité nématicide de l'aldicarbe sur sol lourd, en application fractionnée ou non, contre Xiphinema index Thorne et Allen, 1950 (Nematoda: Longidoridae), vecteur du court-noué de la vigne. Medel Fac Landbouwwet Rijksuniv Gent 53/2b, 885-891

Guesdon JL, Ternynck T, Avrameas S (1979) Use of avidin-biotin interaction in immunoenzymatic techniques. J Histochem Cytochem 27, 1131-1139

Hardie G, Van Regenmortel MVH (1977) Isolation of specific antibody under conditions of low ionic strength. $J$ Immunol Methods 15, 305-314

Rivoal R, Riviere JM (1989) Étude du profil cultural de deux sites, l'un infesté, l'autre non, par Heterodera avenae Woll: conséquences sur le développement radiculaire du blé tendre d'hiver. Agronomie 9, 719728

Scotto la Massese C, Minot JC, Voisin R, Castaing LMR, Fabre A (1988) Influence de la nature du sol, du précédent cultural et de l'âge de la plantation sur la composition et la distribution de la nématofaune associée à la vigne en milieu méditerranéen. Acta Oecol Oecol App/ 9, 137-152

Silva JF, Sequeira OA, Bravo MA, Matos MA (1988) Some ecological aspects of the relationship between grapevine fanleaf virus and its nematode vector Xiphinema index. In: Plant Protection Problems and Prospects of Integrated Control in Viticulture (Cavalloro R, ed) Proc CEC/IOBC Int Symp Lisbon-Vila Real, Portugal, 6-9 June 1988, Comm Eur Commun Joint Res Centre, Ispra, 507-516

Valloton R, Perrier JJ (1990) Les nématodes vecteurs de virus dans le vignoble de Suisse romande et le Tessin. Rev Suisse Vitic Arboric Hortic 22, 53-58

Vuittenez A, Legin R, Kuszala J, Cardin-Munck MC (1972) Les virus NEPO chez la vigne et leurs nématodes vecteurs. Ann Phytopathol 4, 373-392

Vuittenez A (1961) Les nématodes vecteurs de virus et le problème de la dégénérescence infectieuse de la vigne. In: Les Nématodes. Journées d'Etude et d'Information sur la Défense des Cultures. Versailles, 16-17 nov 1961, 1-24 